\title{
KONDISI TERUMBU KARANG DAN ASOSIASINYA DENGAN BINTANG LAUT (Linckia laevigata) DI PERAIRAN PULAU TUNDA, KABUPATEN SERAM, PROVINSI BANTEN
}

\section{CORAL CONDITIONS AND ITS ASSOCIATION WITH STARFISH (Linckia laevigata) IN THE WATER TUNDA ISLAND, SERAM DISTRICT, BANTEN PROVINCE}

\author{
Neviaty P. Zamani ${ }^{1}$ \\ ${ }^{1}$ Departemen Ilmu dan Teknologi Kelautan \\ Fakulltas Perikanan dan Ilmu Kelautan, Institut Pertanian Bogor \\ Korespondensi :np_zamani@yahoo.com
}

\begin{abstract}
Coral reef constitute extremely uniquely ecosystem with various of life forms. A lot of sea star Linckia laevigata were found to associate with coral reef in Tunda Island, Serang Regency, Banten. This research was conducted on JanuaryFebruary 2014 that located in Tunda Island, Serang Regency, Banten. Determination of observatory station was using time swimming (snorkeling) with observing the existence of coral reef and sea star that associated with coral reef. Assessment of coral reef condition was determined by Line Intercept Transect method and abundance of sea star determined by belt transect method. The parameter of water quality were found in entire sites of sampling were still appropriated with coral reef life and sea star. The result showed that coral cover were between 54.95-73.00\%. Life form was dominated by massive and foliose coral. Abundance of Linckia laevigata that found in Tunda Island water was 8-45 ind/100 $\mathrm{m}^{2}$. This association occurred between coral reef and Linckia laevigata that constitute association of the mutualistic symbiosis.
\end{abstract}

Keywords: association, coral reef, sea star, Tunda Island

\begin{abstract}
ABSTRAK
Terumbu karang merupakan ekosistem yang sangat unik dengan berbagai macam bentuk pertumbuhan. Banyak bintang laut jenis Linckia laevigata ditemukan berasosiasi dengan terumbu karang. Penelitian ini dilaksanakan pada bulan Januari-Februari tahun 2014 berlokasi di perairan Pulau Tunda, Kabupaten Serang, Provinsi Banten. Penilaian kondisi terumbu karang dan bintang laut ditentukan dengan metode Line Intercept Transect dan kelimpahan bintang laut yang diterumbu karang ditentukan dengan metode Belt Transect. Parameter kualitas perairan pada seluruh lokasi pengambilan sampel masih sesuai dengan kehidupan terumbu karang dan bintang laut. Hasil penelitian menunjukkan bahwa kondisi terumbu karang pada perairan Pulau Tunda tergolong kategori baik, dengan tutupan karang hidup antara 54.95-73.00\%. Bentuk pertumbuhan didominasi oleh kelompok coral massif dan coral foliose. Kelimpahan bintang laut biru jenis Linnckia laevigata yang ditemukan di perairan Pulau Tunda adalah 8-45 ind $/ 100 \mathrm{~m}^{2}$. Asosiasi ini terjadi antara terumbu karang dan bintang laut jenis Linckia laevigata yang merupakan asosiasi saling menguntungkan (mutualisme).
\end{abstract}

Kata kunci: asosiasi, bintang laut, terumbu karang, Pulau Tunda 


\section{PENDAHULUAN}

Terumbu karang adalah struktur bawah air yang tersusun dari endapan kalsium karbonat $\left(\mathrm{CaCO}_{3}\right)$, yang dihasilkan oleh fauna karang yang pada umumnya dijumpai di perairan tropis. Menurut Veron (1986), terumbu karang masuk dalam filum Cnidaria, kelas Anthozoa, ordo Scleractinia dan memiliki 15 famili. Adapula faktor-faktor fisika dan ekologi yang menjadi pembatas kehidupan terumbu karang yaitu suhu, salinitas, cahaya, sedimentasi, gelombang dan kedalaman. Faktor ekologi yaitu persai ngan, pemangsaan dan grazing (Nybakken 1992). Dalam ekosistem terumbu karang hidup organisme yang berasosiasi yaitu alga, krustasea, moluska, ekinodermata dan ikan (Nontji 2002).

Terumbukarang merupakan ekosistem yang subur dan kaya akan makanan. Struktur fisiknya yang rumit, bercabangcabang, bergua-gua dan berlorong-lorong membuat ekosistem ini habitatnya sangat menarik bagi banyak jenis biota laut baik flora maupun fauna (Romimohtarto \& Juwana 2007). Keberadaan bintang laut pada suatu habitat perairan terumbu karang memiliki arti yang sangat penting karena menimbulkan hubungan timbal balik yang memberi pengaruh pada lingkungannya. Secara tidak langsung, hubungan ini dapat mengindikasikan kondisi perairan yang tengah terjadi, mengingat bahwa organisme dan habitat merupakan subjek pengalir materi dan energi. Organisme yang diketahui menempati habitat yang spesifik akan memudahkan dan mengefisienkan sumber daya dalam menemukannya kelak. Di sisi lain, karakter habitat menjadi salah satu informasi bermanfaat dalam mengevaluasi bentuk dan fungsi tubuh suatu organisme (Blake 1990). Dengan demikian, peran dan manfaat suatu organisme pada habitatnya dapat dimaksimalkan ketika beberapa aspek dasar dari preferensi habitat organisme, seperti karakteristik, pola sebaran, serta densitas dari organisme dan habitatnya telah diketahui. Linckia merupakan salah satu kelompok hewan dalam filum Echinodermata yang memiliki diversitas tertinggi dan dapat ditemukan pada berbagai mikrohabitat perairan (Iken et al. 2010).

Pulau Tunda merupakan salah satu pulau yang berada di daerah utara pulau Jawa, Pulau ini memiliki kawasan terumbu karang yang cukup luas, tetapi struktur komunitas karang dan biota asosiasi khususnya bintang laut jenis Linckia laevigata pada kawasan terumbu karang di perairan Pulau Tunda belum banyak diteliti. Tujuan penelitian ini adalah untuk mendeskripsikan kondisi terumbu karang dan bentuk pertumbuhan yang ada di Pulau Tunda, serta kelimpahan bintang laut jenis Linckia laevigata dan asosiasinya dengan terumbu karang di Pulau Tunda. Manfaat dari penelitian ini diharapkan dapat memberikan informasi dasar bagi pemerintah dan lembaga terkait pengelolaan ekosistem terumbu karang perairan Pulau Tunda.

\section{METODE PENELITIAN}

Penelitian ini dilaksanakan pada bulan Januari-Februari 2014 (dimulai dari pengambilan data hingga pengolahan data dan penyusunan laporan). Lokasi penelitian bertempat di perairan Pulau Tunda, Kabupaten Serang, Provinsi Banten. Penentuan titik-titik pengambilan sampel menggunakan metode time swimming (snorkeling) yaitu seorang peneliti melakukan penyelaman singkat di atas permukaan air sejajar garis pantai untuk melihat kondisi terumbu karang dan keberadaan bintang laut yang berasosiasi dengan terumbu karang sehingga dapat mewakili kondisi terumbu karang dan bintang laut yang berasosiasi dengan terumbu karang secara keseluruhan di lokasi penelitian. Setelah titik lokasi penelitian/titik stasiun telah ditentukan, kemudian dicatat posisi geografisnya menggunakan GPS (Global Position System).

Metode yang digunakan untuk melihat bentuk pertumbuhan karang yaitu metode Line Intercept Transect (LIT) atau metode transek garis, pemasangannya secara horisontal atau sejajar garis pantai. Pengamatan dilakukan dengan melihat bentuk pertumbuhan karang yang bersinggungan dan dilewati oleh garis transek. Pengambilan data atau pengukuran terumbu karang dilakukan menggunakan transek garis sepanjang $20 \mathrm{~m}$. Pengukuran diawali dengan pemasangan transek garis menggunakan meteran roll sepanjang 100 $\mathrm{m}$, kemudian melakukan pengukuran sepanjang $20 \mathrm{~m}$ dengan interval $10 \mathrm{~m}$. Pengukuran pertama dilakukan pada jarak 0-20 m, pengukuran kedua dilakukan pada jarak 40-60 m, pengukuran ketiga dilakukan pada jarak 80-100 m (Gambar 2), sehingga pengukuran yang dilakukan pada setiap stasiun pengamatan sebanyak $3 \mathrm{kali}$ pengambilan sampel. 
Transek sabuk (belt transect) digunakan untuk mengamati bintang laut yang berasosiasi dengan terumbu karang, dimana pemasangan dan cara pengukurannya mengikuti transek garis (Gambar 2). Luasan transek yang digunakan yaitu $40 \mathrm{~m}^{2}$ dengan panjang $20 \mathrm{~m}$ dan lebar transek sepanjang $2 \mathrm{~m}, 1 \mathrm{~m}$ ke atas/ kanan dan $1 \mathrm{~m}$ ke bawah/kiri. Pengamatan dilakukan dengan melihat dan menghitung bintang laut yang berada dalam transek sabuk, setelah itu dihitung kelimpahannya. Dalam rangka mempermudah pengambilan data terumbu karang dan bintang laut yang berasosiasi dengan terumbu karang digunakan kamera bawah air sebagai alat bantu foto atau video bawah air. Adapun pengukuran parameter lingkungan dilakukan secara insitu pada setiap stasiun pengamatan yang meliputi suhu, salinitas, kecepatan arus, kecerahan, dan kedalaman.

\section{Analisis data}

\section{Persentase tutupan karang}

Menurut English et al. (1994) vide Setyobudiandi et al. (2009), persen tutupan karang hidup dihitung dengan menggunakan rumus persen tutupan (cover) sebagai berikut:

$$
\% \text { Cover }=\frac{L_{i}}{L_{t}} \mathrm{X} 100 \%
$$

Keterangan:

$L i=$ Panjang total terumbu karang

$L t=$ Panjang total transek

Menurut Keputusan Menteri Lingkungan Hidup No. 47 Tahun 2001, kondisi penilaian ekosistem terumbu karang berdasarkan persen tutupan karang hidupnya yaitu sebagai berikut:
1. Karang rusak
$=0-24.9 \%$
2. Karang sedang
$=25-49.9 \%$
3. Karang baik
$=50-74.9 \%$
4. Karang sangat baik $=75-100 \%$

\section{Kelimpahan bintang laut}

Kelimpahan bintang laut dihitung dengan persamaan :

$$
\mathrm{D}=\frac{n}{A}
$$

Dimana :

$\mathrm{D}=$ kelimpahan bintang laut (ind $/ \mathrm{m}^{2}$ )

$n=$ jumlah individu bintang laut dit setiap stasiun

$A=$ luas daerah pengamatan

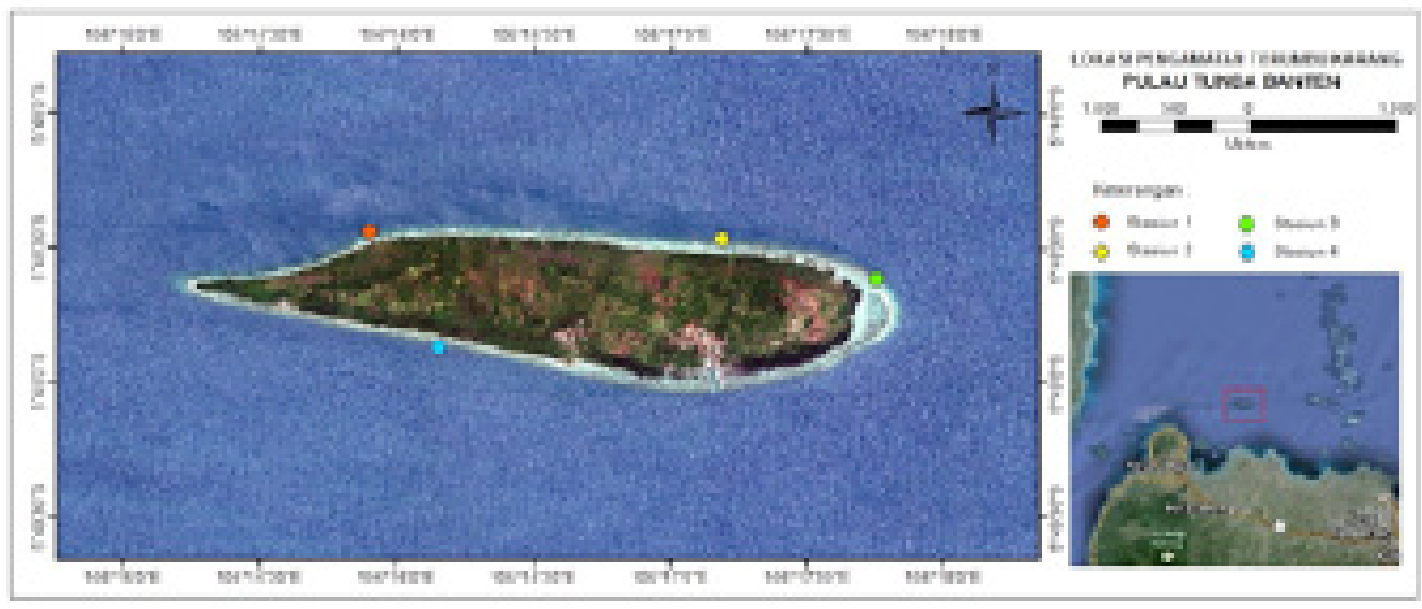

Gambar 1. Lokasi penelitian 


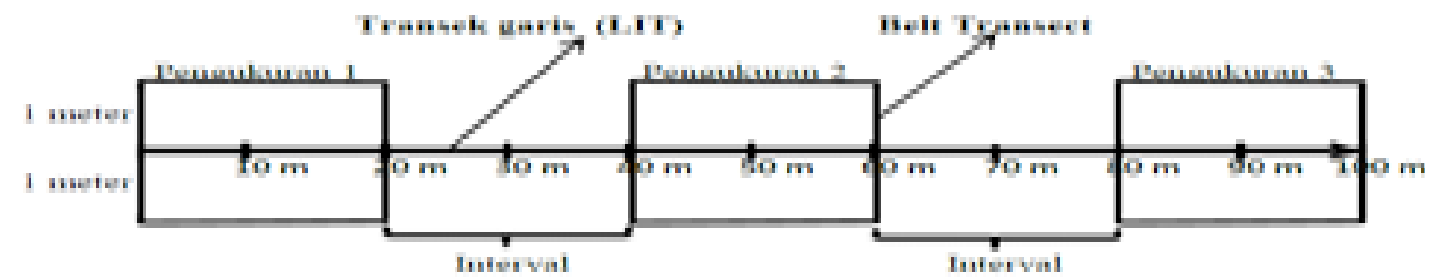

Gambar 2. Sketsa Line Intercept Transect (transek garis) dan Belt Transect (transek)

\section{HASIL DAN PEMBAHASAN}

\section{Persen tutupan karang dan bentuk pertumbuhan karang}

Pengambilan data terumbu karang pada semua stasiun pengamatan dilakukan di perairan Pulau Tunda pada daerah rataan terumbu pada kedalaman 5-10 m. Berdasarkan hasil pengamatan langsung di lokasi pengambilan sampel dapat digambarkan bahwa secara umum terumbu karang pada perairan Pulau Tunda tumbuh dari daerah rataan terumbu sampai ke arah tubir dengan kedalaman sekitar 50 $\mathrm{m}$. Tipe terumbu karang pada perairan pulau ini merupakan tipe terumbu karang tepi, dengan kondisi topografi yang landai sampai dengan curam. Secara umum tipe substrat perairan Pulau Tunda berupa pasir sehingga memungkinkan terumbu karang untuk tumbuh dengan baik pada daerah ini.

Berdasarkan penelitian yang dilakukan, didapatkan persen tutupan karang hidup yang berbeda-beda pada setiap stasiun pengamatan, ditemukan empat bentuk pertumbuhan dari genus Acropora yaitu acropora branching, acropora digitate, acropora submassive, dan acropora tabulate serta enam bentuk pertumbuhan dari genus non-acropora yaitu coral branching, coral encrusting, coral foliose, coral massive, coral submassive, dan coral mushroom. Persentase tutupan karang hidup yang ditemukan pada lokasi pengamatan berkisar antara 54.95$72.30 \%$ dengan kategori baik $67.21 \%$ (Tabel 2). Berdasarkan Tabel 2 terlihat bahwa, persen tutupan karang hidup tertinggi berada pada Stasiun I yaitu $72.30 \%$ dan Stasiun III yaitu 73\%, sedangkan pada Stasiun II tutupan karang hidupnya sebesar $68.58 \%$ dan Stasiun IV tutupan karang hidupnya sebesar $54.95 \%$. Berdasarkan tutupan karang hidupnya Stasiun I, II, III dan IV tergolong kategori baik. Salah satu alasan mengapa terumbu karang di Pulau Tunda masuk dalam kategori baik karena berdasarkan hasil wawancara langsung dengan beberapa masyarakat yang tinggal di pulau tersebut, umumnya mereka menangkap ikan dengan cara yang ramah lingkungan yaitu menggunakan pancing. Hal ini menunjukkan kesadaran masyarakat yang cukup tinggi untuk menjaga lingkungannya khususnya terumbu karang.

Kondisi terumbu karang yang baik ini berdampak baik bagi masyarakat dalam hal menangkap ikan. Akibat banyaknya ikan-ikan karang di sekitar terumbu karang, mereka tidak perlu melakukan penangkapan di daerah yang jauh dari pulau tetapi cukup menggunakan pancing dan perahu kecil karena jarak antara pesisir dan tubir tidak terlalu jauh yaitu sekitar 40 m. Fachry dan Pertamasari (2011) menjelaskan, lima aktivitas utama manusia yang mengancaman kelestarian terumbu karang, yaitu penangkapan ikan dengan bahan beracun, penangkapan ikan dengan bahan peledak, pengambilan batu karang, sedimentasi, dan pencemaran laut. Perairan Pulau Tunda tergolong jernih dengan intensitas cahaya yang cukup tinggi. Air yang jernih sangat diperlukan terumbu karang untuk proses pertumbuhannya. Terumbu karang tidak dapat hidup pada perairan yang keruh karena akan kesulitan menyerap cahaya matahari khususnya zooxanthellae yang merupakan simbion terumbu karang yang sangat tergantung pada intensitas cahaya matahari yang cukup untuk proses fotosintesis. Tidak adanya sungai di daerah ini juga menjadi faktor pendukung tumbuhnya terumbu karang karena umumnya wilayah yang dekat dengan sungai memiliki konsentrasi salinitas yang rendah dan tingkat sedimentasi yang tinggi, dimana kondisi tersebut kurang sesuai untuk pertumbuhan terumbu karang. Menurut Nybakken (1992) kisaran salinitas air laut adalah 30-35 \%o, estuari 5-35 \%o dan air tawar 0.5-5 \%o.

Coral Watch (2011) menjelaskan, zooxanthellae dapat membantu karang 
dalam pembentukan kerangka kapur. Melalui hasil fotosintesisnya, simbion karang ini memungkinkan karang menggunakan cahaya matahari untuk tumbuh dengan baik seperti tumbuhan.Menurut Suharsono (2010) terumbu karang tumbuh oleh karena faktor alam yang sangat mendukung seperti adanya pola arus, air yang jernih, dan tidak banyak sungai besar. Pola arus yang mengalir secara terus-menerus menjamin tersedianya makanan bagi karang, air yang jernih, substrat dasar keras dan lekuklekuk pantai yang dalam serta sedikitnya sedimentasi yang dibawa oleh sungai merupakan jaminan bagi pertumbuhan karang yang ideal.Secara keseluruhan, lokasi pengamatan pada seluruh stasiun memiliki arus yang cukup tinggi sehingga bentuk pertumbuhan karang yang mendominasi pada perairan ini adalah coral massive antara $14.77 \%-22.78 \%$ (Tabel 2) dan coral foliose antara $14.73 \%-20.17 \%$ (Tabel 2). Hal ini disebabkan karena kedua bentuk pertumbuhan tersebut cukup survive untuk mampu bertahan hidup pada kondisi arus yang cukup tinggi.

Kondisi arus ini dapat memberikan suplai oksigen dan makanan seperti plankton yang dibutuhkan terumbu karang, serta dapat membantu terumbu karang dalam membersihkan endapan-endapan yang dapat menganggu pertumbuhannya. Menurut Nybakken (1992) pada umumnya terumbu karang lebih berkembang pada daerah-daerah yang mengalami gelombang yang besar. Johan (2003) menjelaskan, karang masif lebih banyak tumbuh di terumbu terluar dengan perairan berarus sedangkan bentuk bercabang banyak terdapat di sepanjang tepi terumbu dan bagian atas lereng, terutama yang terlindungi atau setengah terbuka. Suharsono (2010) juga menjelaskan coral foliose seperti jenis Montipora tuberculosa banyak tumbuh pada perairan yang berarus. Berdasarkan Tabel 3 , komponen karang mati terdiri dari death coral (karang mati) dan death coral with alga (karang mati yang telah ditumbuhi alga). Pada Stasiun I dan II tidak ditemukan karang mati. Hal ini menunjukkan bahwa kondisi terumbu karang pada kedua wilayah perairan tersebut cukup baik. Adanya karang mati pada Stasiun III dan IV diduga akibat aktivitas perkapalan seperti pembuangan jangkar kapal dan aktivitas wisata berupa penginjakan karang oleh manusia. Karang mati yang telah ditumbuhi alga diduga akibat tekanan dari aktivitas manusia dan faktor lingkungan yang sudah berlangsung lama. Bahartan et al. (2010) menjelaskan, sejak masa lampau, penyebab utama kerusakan terumbu karang adalah akibat tekanan lingkungan dan antropogenik atau tekanan manusia. Terumbu karang dunia telah rusak akibat tekanan manusia sebesar $20 \%$. Menurut Smith et al. (2008) tekanantekanan seperti tekanan lingkungan dan manusia dapat menyebabkan penurunan tutupan karang secara langsung melalui peningkatan angka kematian karang, atau secara tidak langsung melalui peningkatan penyakit karang dan penurunan peremajaan karang untuk dapat pulih kembali dari tekanan tersebut.

Komponen biotik lain yang ditemukan pada stasiun pengambilan sampel terdiri atas soft coral, sponge, dan other (bulu babi, bintang laut, dan lili laut), sedangkan komponen abiotok yang ditemukan terdiri atas sand (pasir) dan rubble (patahan karang). Rendahnya tutupan abiotik, khususnya sand pada seluruh lokasi pengamatan yaitu 1.82-10.87\% (Tabel 3) menunjukkan bahwa distribusi terumbu karang pada daerah ini cukup merata dan formasi penyebarannya cukup padat. Persen tutupan rubble tertinggi ditemukan pada Stasiun IV sebesar $12.30 \%$ (Tabel 3). Hal ini disebabkan karena pada stasiun ini dekat dengan dermaga dan rumah penginapan wisatawan yang berwisata di Pulau Tunda, sehingga dampak pembuangan jangkar kapal dan penginjakan karang merupakan kontribusi terbesar penyebab banyaknya patahan karang. Hasil penelitian menunjukkan bahwa Pulau Tunda sangat cocok untuk dijadikan wisata selam karena keindahan dan keragaman terumbu karangnya, namun tidak dianjurkan bagi penyelam pemula karena perairan Pulau Tunda memiliki arus yang cukup keras. 
Tabel 1. Parameter kualitas air pada tiap stasiun pengamatan

\begin{tabular}{ccccc}
\hline \multirow{2}{*}{ Stasiun } & \multicolumn{4}{c}{ Kandungan nutrisi (\%) } \\
\cline { 2 - 5 } & Suhu $\left({ }^{\circ} \mathbf{C}\right)$ & $\begin{array}{c}\text { Salinitas } \\
\text { (ppt) }\end{array}$ & $\begin{array}{c}\text { Kecerahan } \\
(\%)\end{array}$ & $\begin{array}{c}\text { Kecepatan } \\
\text { Arus (m/s) }\end{array}$ \\
\hline I & 26 & 30 & 100 & 0.06 \\
II & 28 & 31 & 100 & 0.19 \\
III & 28 & 31 & 100 & 0.12 \\
IV & 29 & 32 & 100 & 0.05 \\
\hline
\end{tabular}

Tabel 2. Bentuk pertumbuhan dan persen tutupan karang hidup pada tiap stasiun pengamatan

\begin{tabular}{lllll}
\hline \multirow{2}{*}{ Bentuk Pertumbuhan } & \multicolumn{4}{c}{ Stasiun } \\
\cline { 2 - 5 } I & \multicolumn{1}{c}{ II } & III & IV \\
\hline Acropora & & & & \\
Acropora branching (ACB) & 14.05 & 17.80 & 5.08 & 4.37 \\
Acropora digitate (ACD) & 0.00 & 1.87 & 5.42 & 1.78 \\
Acropora submassive (ACS) & 1.15 & 1.47 & 0.00 & 0.00 \\
Acropora tabulate (ACT) & 9.23 & 7.07 & 4.75 & 6.85 \\
Sub Total & 24.43 & 28.20 & 15.25 & 13.00 \\
Non Acropora & & & & \\
Coral branching (CB) & 2.83 & 1.82 & 2.50 & 3.17 \\
Coral encrusting (CE) & 7.17 & 4.17 & 2.33 & 2.33 \\
Coral foliose (CF) & 18.60 & 14.73 & 20.17 & 15.92 \\
Coral massive (CM) & 14.77 & 22.78 & 18.67 & 18.62 \\
Coral submassive (CS) & 4.60 & 2.17 & 9.42 & 1.50 \\
Coral mushroom (CMR) & 1.90 & 0.50 & 5.67 & 1.38 \\
Sub Total & 47,87 & 40,38 & 57,75 & 41.95 \\
Total & 72.30 & 68.58 & 73.00 & 54.95 \\
Kriteria Tutupan & Baik & Baik & Baik & Baik \\
\hline
\end{tabular}

Tabel 3. Persen tutupan karang mati, biotik lain, dan abiotik pada tiap stasiun pengamatan

\begin{tabular}{|c|c|c|c|c|}
\hline \multirow{2}{*}{ Persen Tutupan } & \multicolumn{4}{|c|}{ Stasiun } \\
\hline & I & II & III & IV \\
\hline \multicolumn{5}{|l|}{ Karang Mati } \\
\hline Death Coral (DC) & 0 & 0 & 1.00 & 4.22 \\
\hline Death Coral with Alga (DCA) & 0 & 0 & 0 & 2.12 \\
\hline \multicolumn{5}{|l|}{ BIOTIK LAIN } \\
\hline Soft Coral (SC) & 3.05 & 11.20 & 7.42 & 6.78 \\
\hline Sponge (SP) & 3.42 & 0 & 2.92 & 2.75 \\
\hline Others (OT) & 15.35 & 14.10 & 5.75 & 6.02 \\
\hline \multicolumn{5}{|l|}{ ABIOTIK } \\
\hline Sand (SD) & 2.87 & 1.82 & 3.17 & 10.87 \\
\hline Rubble (RB) & 3.02 & 2.93 & 6.75 & 12.30 \\
\hline
\end{tabular}




\section{Kelimpahan bintang laut}

Echinodermata berasal dari bahasa Yunani Echinus berarti landak dan derma berarti kulit. Semua jenis Echinodermata hidup di laut, mulai dari daerah litoral sampai kedalaman $6 \mathrm{~m}$. Termasuk dalam filum Echinodermata antara lain bintang laut, bulu babi, teripang dan lain-lain. Umumnya berukuran besar dan yang terkecil berdiameter $1 \mathrm{~cm}$ (Brotowidjoyo 1994). Pada perairan Indonesia dan sekitarnya (kawasan India Pasifik Barat) terdapat teripang kurang lebih 141 jenis, bintang laut 87 jenis, bintag ular 142 jenis, bulu babi 84 jenis dan lili laut 91 jenis (Nontji 1993).

Bintang laut sebenarnya adalah makhluk hidup yang bebas, namun dikarenakan ketiadaan organ gerak yang memadai, bintang laut hanya bergerak mengikuti arus air laut hewan ini banyak dijumpai di pantai. Bintang laut memiliki kekuatan regenerasi yang mengagumkan. Apabila satu lengan putus, lengan baru akan tumbuh kembali. Bila cakram tengah ditempelkan ke tangan yang terpotong, individu baru dapat tumbuh dari bagian yang terpotong tersebut (Niel et al. 2003). Sistem reproduksi pada bintang laut, yaitu dengan sistem fertilisasi yang terjadi di luar eksternal, yaitu di dalam air laut atau di luar tubuhnya. Telur yang telah dibuahi akan membelah secara cepat menghasilkan blastula, dan selanjutnya berkembang menjadi gastrula. Gastrula ini berkembang menjadi larva. Larva atau disebut juga bipinnaria berbentuk bilateral simetri. Larva ini berenang bebas di dalam air mencari tempat yang cocok hingga menjadi branchidaria, lalu mengalami metamorfosis dan akhirnya menjadi dewasa, setelah dewasa bentuk tubuhnya berubah menjadi radial simetri.

Dari hasil pengamatan yang dilakukan di Pulau tunda, bintang laut yang ditemukan yaitu dari jenis Linckia laevigata (Gambar 3). Linckia laevigata (atau sering disebut "Linckia biru" atau bintang laut biru) adalah spesies bintang laut di perairan dangkal tropis Indo-Pasifik, bintang laut ini dapat tumbuh hingga 30 $\mathrm{cm}$, dengan bulatan pada setiap lengan, pada beberapa individu terdapat bintikbintik terang atau lebih gelap di sepanjang masing-masing lengan mereka. Genus Linckia, seperti halnya spesies lain dari laut, diakui oleh para ilmuwan sebagai makhluk yang memiliki kemampuan regeneratif yang luar biasa, dan diberikan kekuatan defensif autotomy terhadap predator. Meskipun belum didokumentasikan, Linckia laevigata mungkin dapat bereproduksi secara aseksual, seperti halnya spesies terkait Linckia multifora (penghuni lain dari laut tropis, tetapi berbeda warna, yaitu merah muda atau kemerahan berbintik-bintik dengan warna putih dan kuning, yang telah diamati mereproduksi secara aseksual dalam penangkaran) Linckia multifora menghasilkan 'komet', atau lengan terpisah, dari individu induknya.

Berdasarkan pengamatan yang dilakukan, bintang laut jenis Linckia laevigata yang ditemukan berkisar antara 3-18 individu dengan kelimpahan 8-45 ind/100 $\mathrm{m}^{2}$ (Tabel 4). Dari keempat stasiun yang diamati, individu Linckia laevigata yang paling banyak ditemukan yaitu pada Stasiun II dengan kelimpahan sebesar 45 ind/100 $\mathrm{m}^{2}$ (Tabel 4). Jika dilihat dari tutupan karang hidupnya, Stasiun II memiliki tutupan karang hidup yang lebih kecil dibanding yang lain yaitu sebesar (68.58\%) (Tabel 2), namun kondisi ini masih dalam kategori baik dan tidak berbeda jauh dengan Stasiun I dan III yang memiliki tutupan karang hidup tertinggi yaitu $72.30 \%$ dan 73\% (Tabel 2).

Jika dilihat dari kecepatan arusnya, Stasiun II memiliki kecepatan arus yang lebih tinggi yaitu $0.19 \mathrm{~m} / \mathrm{s}$ dibandingkan stasiun lain. Hal inilah kemungkinan yang menjadi alasan individu Linckia laevigata cukup melimpah di wilayah ini akibat ketersediaan makanan yang cukup yaitu berupa alga karena Linckia laevigata juga dikenal sebagai pemakan alga. Alga yang hidup di daerah ini merupakan alga yang dapat bertahan pada kondisi arus yang tinggi yaitu tumbuh dengan daun yang sempit dan pipih untuk menyesuaikan diri pada keadaan tersebut. Gerakan air diperlukan untuk mempercepat difusi gas dan ion-ion dalam air. Dengan lancarnya difusi gas dan ion-ion yang diperlukan oleh alga, maka pertumbuhan alga akan menjadi lebih cepat. Gerakan air juga membantu menyuplai zat hara dan membersihkan kotoran yang menempel pada alga.

Alasan lain adalah seperti halnya stasiun lain, pada Stasiun II memiliki substrat berupa pasir, batuan karang dan benda-benda padat yang kebetulan tenggelam di laut yang menjadi tempat penempelan alga. Selain itu, wilayah ini juga ketika surut masih tergenang air sehingga memungkinkan Linckia laevigata untuk tetap tumbuh karena habitat hewan 
ini yaitu pada wilayah yang tergenang dan substrat berpasir walaupun sebagian ada juga yang membenamkan diri dalam lumpur. Sebagaimana fauna echinodermata lainnya, bintang laut juga dikenal sebagai penghuni laut sejati, dengan batasan toleransi salinitas antara $30 \%$ sampai dengan $34 \%$. Jenis bintang laut tertentu ada yang dapat bertahan hidup pada salinitas sekitar $15 \%$ (di laut baltik). Jenis-jenis bintang laut ini telah mengalami adaptasi melalui periode waktu yang lama (Feder 1966). Pola zonasi fauna echinodermata khususnya bintang laut di suatu lokasi terumbu karang, tidak dapat dijadikan suatu patokan ukuran untuk menggambarkan pola zonasi fauna echinodermata di tempat lain (Hammond et al. 1985). Menurut Namboodiri \& Sivadas (1979) zonasi bisa dikaitkan dengan pendekatan bentuk dan macam substrat. Sloan (1980) juga menjelaskan bahwa sebagian besar bintang laut hidup di ekosistem terumbu karang, bintang laut Linckia Laevigata merupakan pemakan detritus dan lapisan busukan dari biota sessil bentos (Sloan 1980).

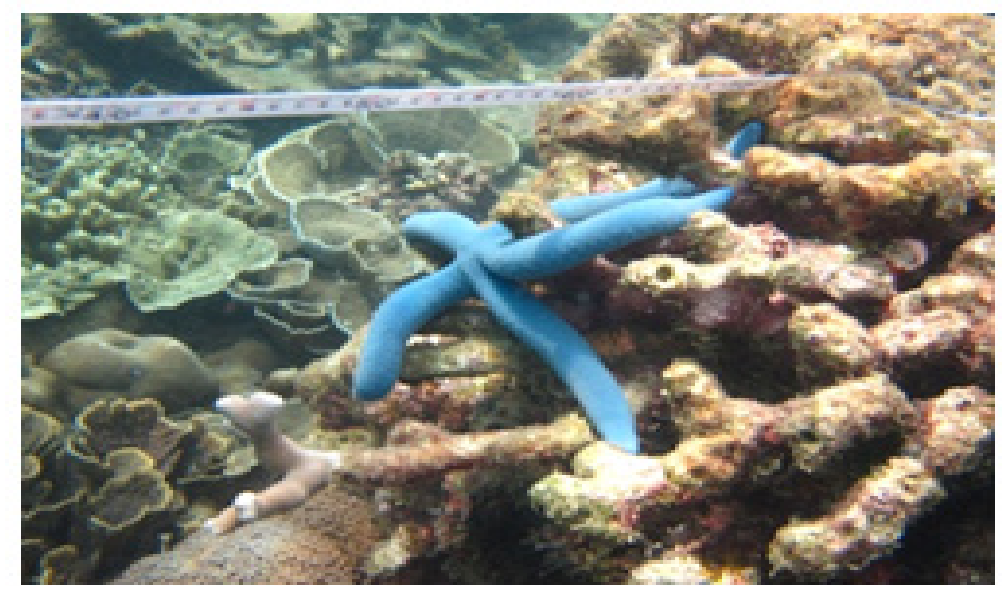

Gambar 3. Bintang laut biru jenis Linckia laevigata yang ditemukan pada lokasi pengamatan

Tabel 4. Kelimpahan bintang laut pada tiap stasiun pengamatan

\begin{tabular}{ccccc}
\hline $\begin{array}{c}\text { Stasiun } \\
\text { Pengamatan }\end{array}$ & $\begin{array}{c}\text { Jumlah } \\
\text { Individu }\end{array}$ & $\begin{array}{c}\text { Luas Transek } \\
\left(\mathbf{m}^{\mathbf{2}}\right)\end{array}$ & $\begin{array}{c}\text { Kelimpahan (ind/100 } \\
\left.\mathbf{m}^{\mathbf{2}}\right)\end{array}$ & $\begin{array}{c}\text { Kelimpahan } \\
\left(\mathbf{i n d} / \mathbf{1 0 0} \mathbf{~ m}^{\mathbf{2}}\right)\end{array}$ \\
\hline I & 12 & 40 & 0.30 & 30 \\
II & 18 & 40 & 0.45 & 45 \\
III & 9 & 40 & 0.23 & 23 \\
IV & 3 & 40 & 0.08 & 8 \\
\hline
\end{tabular}

Asosiasi antara terumbu karang dan bintang laut

Suatu organisme melakukan asosiasi kemungkinan karena ingin mendapatkan keuntungan dari asosiasi yang dilakukannya. Ada yang sifatnya saling menguntungkan (mutualisme), saling merugikan (parasitisme), dan yang satu diuntungkan sedangkan yang lain tidak mendapatkan keuntungan (komensalisme) dari asosiasinya terhadap simbionnya.

Sebagian besar wilayah perairan terdapat banyak sekali jenis makhluk hidup yang saling berasosiasi atau berinteraksi. Penyebab utama adanya interaksi diantaranya adalah ketersediaan makanan. Terumbu karang merupakan ekosistem yang subur dan kaya akan makanan, sehingga berbagai jenis biota laut tertarik untuk hidup pada ekosistem tersebut. Salah satu biota laut yang hidup dan berasosiasi dengan terumbu karang adalah dari filum echinodermata. Hampir sebagian besar hewan anggota filum echinodermata hidup di perairan laut, sebagian kecil lainnya hidup di perairan payau tetapi tidak ada yang hidup di perairan tawar. Penyebaran hewan 
echinodermata cukup luas dimana tidak hanya ditemukan pada ekosistem terumbu karang, tetapi juga dapat ditemukan pada ekosistem mangrove dan lamun, namun dari segi keanekaragaman, keanekaragaman echinodermata lebih tinggi di ekosistem terumbu karang.

Lima kelompok besar hewan echinodermata yang biasa ditemui di terumbu karang adalah bintang laut, bintang ular, bulu babi, teripang, dan lili laut. Di antara kelima organisme tersebut, Linckia laevigata merupakan yang paling umum ditemui pada ekosistem terumbu karang karena warnanya yang cukup terang dan mencolok. Selain itu, dari segi ukuran bintang ular dan lili laut, lebih kecil dari Linckia Laevigata, adapun dari segi habitat, bintang ular dan lili laut biasa hidup dan bersembunyi di antara celah-celah terumbu karang bercabang, sedangkan Linckia laevigata biasanya hidup di atas terumbu karang.

Bintang laut biru jenis Linckia laevigata merupakan jenis bintang laut yang asosiasinya tidak berbahaya bagi terumbu karang. Berbeda dengan bintang laut mahkota duri (Acanthaster planci) yang asosiasinya dengan terumbu karang dapat merugikan terumbu karang karena hewan ini merupakan predator utama terumbu karang karena makanan utamanya adalah polip karang. Linckia laevigata memanfaatkan terumbu karang sebagai area untuk mendapatkan makanan yang cukup dari organisme lain yang hidup di sekitar terumbu karang, sehingga tidak jarang dalam ekosistem terumbu karang sering kita jumpai bintang laut khusunya bintang laut biru jenis Linckia laevigata. Menurut Aziz (1996) berdasarkan jenis makanannya, biota ini termasuk pemakan sisa-sisa organisme lain (scavenger), kemungkinan juga pemakan jamur (saprofit), bahkan juga bisa disebut sebagai pemakan mikroalga (grazer). Bintang laut tergolong hewan omnivor. Interaksi yang terjadi antara terumbu karang dan bintang laut adalah interaksi (asosiasi) mutualisme. Linckia Laevigata mendapatkan makanan dari hewan-hewan yang hidup di sekitar terumbu karang seperti alga, sepon, keong, kerang, bulu babi dan endapan bahan organik yang terperangkap di terumbu karang, sedangkan terumbu karang juga mendapatkan keuntungan dari sifat makan Linckia laevigata. Makanan Linckia laevigata adalah kotoran dan bangkai laut atau disebut juga sebagai detrivor yaitu pemakan materi organik. Dari sifat makan ini, Linckia Laevigata berperan dalam menjernihkan laut sehingga dapat memberikan keuntungan bagi terumbu karang karena salah satu faktor pembatas kehidupan terumbu karang adalah kecerahan atau kekeruhan. Makin jernih suatu perairan maka semakin baik pertumbuhan terumbu karang, begitupun sebaliknya makin keruh suatu perairan, maka pertumbuhan terumbu karang akan terganggu atau terhambat, dan jika kekeruhan tersebut berlangsung dalam waktu yang lama dan melebihi batas toleransi terumbu karang untuk bertahan hidup, maka dapat meyebabkan kematian terhadap terumbu karang. Makanan lain Linckia laevigata adalah alga. Selain zoohanthella, juga terdapat jenis alga lain yang hidup di sekitar terumbu karang dan bersifat parasit bagi terumbu karang. Alga yang terlihat pada lokasi pengamatan adalah alga hijau (chlorophyta). Hal ini karena alga jenis ini biasnya hidup pada perairan dekat permukaan dengan intensitas cahaya matahari yang tinggi, sedangkan alga jenis lain yaitu alga cokelat dan merah biasanya hidup pada daerah perairan yang lebih dalam dengan intensitas cahaya matahari yang cukup rendah.

Alga merupakan salah satu pesaing terumbu karang dalam mendapatkan ruang untuk bertahan hidup. Pertumbuhan terumbu karang akan terganggu dengan banyaknya alga dalam suatu perairan. Semakin banyak alga, maka dominasi terumbu karang semakin berkurang. Sebelum mengalami kematian, terlebih dahulu terumbu karang akan terkena penyakit baik yang berasal dari dari faktor alam maupun lingkungan. Terumbu karang dapat memulihkan diri ketika terserang penyakit, tapi membutuhkan waktu yang lama. Ketika terumbu karang sakit, maka alga akan tumbuh di atas terumbu karang. Ketika alga tersebut teluh mendominasi individu terumbu karang, maka terumbu karang akan sulit untuk memulihkan diri dari penyakit. Dengan adanya Linckia laevigata sebagai pemakan alga, dapat mengendalikan populasi alga dalam suatu perairan sehingga terumbu karang dapat tumbuh dan berkembang dengan baik.

\section{KESIMPULAN}

Kesimpulan dari penelitian ini adalah kondisi terumbu karang pada perairan Pulau Tunda tergolong kategori baik, dengan tutupan karang hidup antara 54.95-73.00\%, 
bentuk pertumbuhan yang mendominasi adalah dari kelompok coral massif dan coral foliose, kelimpahan bintang laut biru jenis Linckia laevigata yang ditemukan di perairan Pulau Tunda adalah 8-45 ind/100 $\mathrm{m}^{2}$, asosiasi yang terjadi antara terumbu karang dengan bintang laut jenis Linckia laevigata merupakan asosiasi yang bersifat saling menguntungkan (mutualisme).

\section{DAFTAR PUSTAKA}

Bahartan K, Zibdah M, Ahmed Y, Israel A, Brickner I, Abelson A. 2010. Macroalgae in the coral reefs of eilat (gulf of aqaba, red sea) as a possible indicator of reef degradation. Marine Pollution Bulletin. 60(5) :759-764.

Blake DB. 1990. Adaptive zones of the class asteroidea (echinodermata). Bulletin of Marine Science. 46(3):701-718.

Coral Watch. 2011. Terumbu karang dan perubahan iklim, panduan pendidikan dan pembangunan kesadartahuan. Australia : The University of Queensland.

Fachry ME, Pertamasari A. 2009. Analisis efektifitas metode penyuluhan pada masyarakat pesisir di Kabupaten Pangkep Sulawesi Selatan. Jurnal Agribisnis. 10(3):69-80.

Hammond LS, Britles RA, Reichelt RE. 1985. Holothuroid assemblages on coral reefs across central section of the great barrier reef. Proc. 5th Internat. Coral Reef Cngr. Tahiti.

Iken K, Konar B, Benedetti-Cecchi L, Cruz-Motta JJ, Knowlton A, Pohle G, Mead A, Miloslavich P, Wong M,
Trott T. 2010. Large-scale spatial distribution patterns of echinoderms in nearshore rocky habitats. PLOS ONE. 5(11):e13845.

Johan O. 2003. Metode Survey Terumbu Karang Indonesia. Jakarta: Yayasan Terangi.

Namboodiri. PN, Sivadas P. 1979. Zonation of molluscan assemblage at Karavatti Atoll (laccadive). Mahasagar Bull. 12 (3):239-246.

Niel AC, Jane BR, Lawrence GM. 2003. Biologi. $5^{\text {th }}$ edition. Jakarta: Penerbit Erlangga.

Nontji A. 2002. Laut Nusantara. Jakarta: Djambatan.

Nybakken JW. 1992. Biologi Laut, Suatu Pendekatan Ekologis. Jakarta: Penerbit PT. Gramedia.

Romimohtarto K, Juwana S. 2007. Biologi Laut : Ilmu Pengetahuan Tentang Biota Laut. Jakarta: Penerbit Djambatan

Smith TB, Nemeth RS, Blondeau J, Calnan JM, Kadison E, Herzlieb S. 2008. Assessing coral reef health across onshore to offshore stress gradients in the US Virgin Islands. Center for Marine and Environmental Studies. University of the Virgin Islands. 56(12) :83-91.

Suharsono. 2010. Jenis-Jenis Karang di Indonesia. Jakarta: Lipi Coremap Program.

Supriharyono. 2007. Pengelolaan Ekosistem Terumbu Karang. Jakarta: Djambatan.

Sloan NA. 1980. Aspects of feeding biology of asteroidea. Oceanogr. Mar. Biol. Ann. Rev. 18 :57-124. 